\title{
TERAPI MUSIK MENURUT AL-FARABI PADA MASA DINASTI ABBASIYAH (942-950 M)
}

\author{
Ro Hani ${ }^{1,2}$ \\ Suryo Ediyono ${ }^{1}$ \\ ${ }^{1}$ Program Studi Sastra Arab Fakultas Ilmu Budaya \\ Universitas Sebelas Maret Surakarta. \\ 2Email: rohani@student.uns.ac.id
}

\begin{abstract}
This study was intended to describe the functions and instruments of music during the Abbasid Dynasty and to describe music therapy according to Al-Farabi. The research method used is the descriptive qualitative method, where the data were technically collected using the library technique, then the data were analyzed based on the formulated problem, following after it describes the analysis results in the form of a written report. The data sources are the reference books related to Al-Farabi. The data of this study used Mūsì $A l-K a b i \bar{r}$, books, theses, journals related to the research. Based on this research, it can be concluded that the art of music began to develop rapidly during the Abbasid caliphate, and music can be used as a therapy for the soul, spiritual, and psychosomatic..
\end{abstract}

Keywords: Music art, Music therapy, Abbasid Dynasti, Al-Farabi.

$$
\begin{aligned}
& \text { ملخص } \\
& \text { يهدف هذا البحث إلى وصف أغراض وآلات فن الموسيقى العربي في عهد الدولة العباسية ووصف العلاج الموسيقي } \\
& \text { عند الفارابي. المنهج البحث المتبع المنهج الوصفي والنوعي المتضمن على مرحلة جمع البيانات بالتقنية المرجعية ومرحلة } \\
& \text { تحليل البيانات وعرض نتائج التحليل. بيانات البحث هو الكتاب الموسيقي الكبير تأليف الفارابي، وبجموعة من المراجع } \\
& \text { والمجلات العلمية المتعلقة بموضوع البحث. وتدل نتائج البحث على أن الفن الموسيقي يتطور كثيرا في عهد الدولة } \\
& \text { العباسية، وأن للموسيقى وظيفة العلاج للنفس والقلب والنفس الحركي. } \\
& \text { الكلمات المفتاحية: فن الموسيقي، العلاج الموسيقي، الدولة العباسية، الفارابي. }
\end{aligned}
$$

\section{A. Pendahuluan}

Musik memiliki peranan penting dalam kehidupan sehari-hari, yakni dapat digunakan sebagai media komunikasi, hiburan dan lain sebagainya. Fungsi awal dari musik adalah sebagai media penghibur. Musik yang dimainkan secara bersamasama akan menghasilkan suara yang ramai dan menghibur, sebagai media ekspresi diri (self ekspresion), representasi simbolis, respon fisik, media terapeutik (penyembuhan), sebagai sarana pemersatu masyarakat yang sedang mengalami krisis, menguatkan konformitas terhadap normanorma sosial, memvalidasi institusi-institusi sosial dan ritual-ritual keagamaan, memelihara kontinuitas dan stablitas budaya, dan sebagai media pendidikan serta pembelajaran (Budhisantoso, 1994; Merriam, 1968; dan Merrit, 2003). 
Seni budaya pada masa Kekhalifahan Abbasiyah telah ada sejak dinasti ini berdiri sebagai lanjutan dari kekuasaan Bani Umayyah kemudian seni budaya dimasa ini terus mengalami perkembangan begitu pesat pada periode pertama Bani Abbasiyah (750-847). Kemajuan seni zaman Abbasiyah dipengaruhi diantaranya adalah asimilasi antara Bangsa Arab dan etnis-etnis lain yang lebih dahulu mengalami perkembangan dalam bidang seni. Pengaruh Persia sangat penting di bidang seni, selain itu mereka juga berjasa dalam perkembangan ilmu filsafat dan sastra sedangkan pengaruh Yunani masuk melalui terjemah-terjemah dalam banyak bidang ilmu terutama filsafat (Karim, 2012:167). Seiring berjalannya waktu banyak musisi ternama yang yang bermunculan pada masa tersebut di antaranya Sa'ib Khathir (wafat $683 \mathrm{M}$ ), Tuwais (wafat $710 \mathrm{M}$ ), Ibnu Mijjah (wafat 714 M), Ishaq Al-Mausili (767-850), AlKindi (800-877 M), serta Al Farabi (872$950 \mathrm{M})$. Peradaban Islam juga mewariskan instrumen musik yang termasuk penting bagi masyarakat modern yang menjadi cikal bakal alat musik yang ada di dunia antara lain Alboque atau Alboka, Qanun (Kecapi) dan 'Ud, Hurdy Gurdy dan Instrumen Musik Keyboard Gesek, Timpani, Naqqāra atau Naker, Rebab.

Para ilmuwan Dinasti Abbasiyah memiliki perhatian besar terhadap seni musik salah satunya yaitu Abu Nashr AlFarabi atau lebih dikenal dengan Al-Farabi. Al-Farabi tidak hanya terkenal sebagai filsuf yang pandai, akan tetapi ia juga di kenal sebagai musikus yang handal dan pandai dalam memainkan alat musik, ia disebut sebagai penemu alat musik rebab dan qanun. Al-Farabi berpandangan bahwa musik dapat menciptakan ketenangan dan mampu mengendalikan emosi seseorang, mengembangkan spiritualitas, serta musik dapat digunakan sebagai alat terapi penyembuhan penyakit seperti gangguan psikosomatik. Al-Farabi dalam kitab alMusiq al-Kabir juga memperkenalkan solmisasi "do re mi fa sol la si do". Selain itu mereka juga berjasa dalam perkembangan ilmu filsafat dan sastra, pengaruh Yunani masuk melalui terjemahterjemah dalam banyak bidang ilmu terutama filsafat (Karim, 2012:167). Penelitian ini bertujuan untuk mendeskripsikan perkembangan musik pada Dinasti Abbasiyah dan menguraikan tentang terapi musik menurut Al-Farabi.

\section{B. Metodologi Penelitian}

Penelitian ini menggunakan metode deskriptif kualitatif yaitu pengumpulan data menggunakan teknik pustaka, kemudian data dianalisis berdasarkan rumusan masalah, setelah itu mendeskripsikan hasil analisis ke dalam bentuk laporan tertulis. Sumber data berupa buku referensi yang berhubungan dengan Al-Farabi. Sumber data penelitian yang digunakan adalah Mūsīq Al-Kabìr, buku referensi, artikel jurnal yang terkait dengan penelitian tersebut. Pengumpulan sumber yaitu proses yang dilakukan peneliti untuk mengumpulkan sumber-sumber, data-data, atau jejak sejarah. Sejarah tanpa sumber maka tidak bisa bicara. Maka sumber dalam penelitian sejarah merupakan hal paling utama yang akan menentukan bagaimana aktualitas masa lalu manusia dapat dipahami. Data penelitian ini diperoleh melalui sumber kepustakaan (literature) yaitu mengambil data dari berbagai buku dan insiklopedia, dan lain sebagainya, seperti buku Mūsìq Al-Kabìr (Musik Besar), buku Integrasi Agama dan Filsafat Pemikiran Epistemologi Al-Farabi, buku Puncak Kebahagiaan (Al-Farabi) EtapeEtape Sufistik Filosofis Meniti Revolusi Hidup. Analisis data adalah untuk menetapkan bahwa sumber tersebut mencerminkan realitas historis, serta seberapa reliable (Abdurrahman, 1999:64). Dalam penyajian data, peneliti dituntut untuk menyajikan dengan bahasa yang baik, yang dapat dipahami oleh orang lain dan dituntut untuk menguasai teknik penulisan karya ilmiah. Penulisan hasil penelitian 
sejarah ini memberikan gambaran yang jelas mengenai proses penelitian sejak awal sampai dengan kesimpulan atau akhir.

\section{Pembahasan}

\section{Musik: Fungsi dan Alat-alatnya}

Menurut bentuknya, musik dapat dibedakan menjadi tiga macam yaitu musik vokal, instrumental, dan musik campuran. Musik vokal adalah karya musik yang dinyanyikan dengan suara manusia. Musik instrumental adalah karya musik yang dimainkan dengan alat musik (instrumen), dan musik campuran adalah perpaduan antara musik vokal dan musik instrumental. Penggunaan musik berhubungan dengan situasi dimana musik diperlakukan diantara kegiatan manusia, sedangkan fungsi musik menyangkut tujuan dalam memenuhi kebutuhan sosial (Merriam, 1964:210). Musik merupakan kebutuhan yang universal yang keberadaannya tidak dapat terpisahkan dalam bebagai peristiwakehidupan manusia. Ada berbagi fungsi musik diantaranya adalah:

(1) Musik sebagai pengungkapan emosional, sebagai pengungkapan emosionalyaitu sebagai media untuk mengekspresikan perasaan emosional manusia. Ide-ide dari perasaan manusia diungkapkan dalam bentuk musik. Itulah mengapa banyak berbagai macam suasana dalam musik, ada yang memiliki suasana ceria, hangat, sepi, sedih, seram, menegangkan, dan lain sebagainya.

(2) Musik sebagai kepuasan estetis, kepuasan estetis yaitu musik memberikan ketenangan jiwa kepada pendengarnya dengan keindahan yang ada di dalam musik. Seseorang akan merasa senang apabila mendengarkan musik kesukaannya. Melalui keunikan melodis, ritmis, dan harmonis maupun terkait dengan komposisi dan instrumenasinya tersebut seseorang dapat mersakan nilai-nilai keindahan. Suatu karya dapat dikatakan karya seni apabila memiliki unsur keindahan atau estetika di dalamnya. Melalui musik kita dapat merasakan nilai- nilai keindahan baik melalui melodi maupun dinamikanya.

(3) Musik sebagai hiburan, musik sebagai hiburan yaitu musik mampu membuat perasaan gembira dan memberikan perasaan senang kepada pendengarnya. Musik memiliki fungsi menyenangkan hati, membuat rasa puas dengan irama, bahasa melodi, atau keteraturan dari harmoni musik. Musik sebagai obat penghilang rasa bosan dan kegelisahan hidup manusia serta sebagai media rekreatif yang menanggalkan segala macam kepenatan dan keletihan dalam aktivitas sehari-hari (Setyobudi dkk, 2007:47).

(4) Musik sebagai sarana komunikasi, musik sebagai sarana komunikasi yaitu di dalam sebuah musik yang berlaku di suatu daerah kebudayaan mengandung isyarat-isyarat maupun pesanpesan terdapat pada melodi lagu dan syair (lirik lagu) yang mengandung nilai-nilai religi atau kepercayaan dan nilai-nilai mengenai kesopanan atau norma melalui lagu. Fungsi musik sebagai alat komunikasi adalah sebagai media penyampaian nilainilai kebaikan melalui melodi maupun lirik lagu dari pencipta musik kepada para pendengar.

(5) Musik sebagai perlambangan, musik sebagai perlambangan yaitu musik memiliki fungsi dalam melambangkan suatu hal. Hal ini dapat dilihat dari aspek-aspek musik tersebut, contohnya tempo sebuah musik, jika tempo musik lambat, maka kebanyakan teksnya menceritakan hal-hal yang menyedihkan. Musik juga dapat menjadi lambang suatu negara atau daerah. Misalnya lagu Indonesia Raya merupakan perlambangan dari negara Indonesia.

(6) Musik sebagai reaksi jasmani, musik sebagai reaksi jasmani yaitu musik sebagai pengiring aktivitas ritmik. Misalnya tari-tarian, senam, dan dansa. Musik dapat membuat pendengarnya bergerak mengikuti alunan musik. Musik merangsang sel-sel syaraf manusia sehingga menyebabkan 
tubuh manusia bergerak mengikuti irama musik.

(7) Musik sebagai pengesahan lembaga sosial, musik sebagai pengesahan lembaga sosial, fungsi musik disini berarti bahwa sebuah musik memiliki peranan yang sangat penting dalam suatu upacara, musik merupakan salah satu unsur yang penting dan menjadi bagian dalam upacara, bukan hanya sebagai pengiring. Artinya musik sebagai bagian dari kehidupan manusia yang memliki peradaban dan kebudayaan.

(8) Musik yang berkaitan dengan norma-norma sosial, musik yang berkaitan dengan norma-norma sosial yaitu musik berfungsi sebagai media pengajaran akan norma-norma atau peraturan-peraturan. Penyampaian kebanyakan melalui teks-teks nyanyian yang berisi aturan-aturan. Musik sebagai sebuah karya cipta mengandung nilai sosial yang dapat memberi kontribusi terhadap tatanan hidup masyarakat, baik secara individu maupun kelompok.

(9) Musik sebagai kesinambungan budaya,musik sebagai kesinambungan budaya, fungsi ini hampir sama dengan fungsi yang berkaitan dengan norma sosial. dalam hal ini musik berisi mengenai ajaranajaran untuk meneruskan sebuah sistem dalam kebudayaan terhadap generasi selanjutnya. Setiap negara di dunia pasti memiliki sebuah musik tradisional sebagai salah satu ciri khas kebudayaannya. Ketika orang-orang mendengar musik tersebut mereka akan langsung mengingat daerah dimana musik tersebut berasal.

(10) Musik sebagai pengintegrasian masyarakat, musik sebagai pengintegrasian masyarakat yaitu musik dapat memberikan pengaruh dalam proses pembentukan kelompok sosial di dalam masyarakat, musik mempersatukan masyarakat di dalam sebuah forum musik. Musik pada dasarnya merupakan naluri manusia yang diciptakan karena kebutuhan dan kesenangan batin. Dengan mengeluarkan lagu dari sisi-sisi yang beragam ketika ia terketuk ke dalam jiwa, jiwa measa adanya kenikmatan yang berdampak pada kesehatan dan ketenangan saat terjadi ketukan, jika sebaliknya maka jiwa merasa gelisah dan sakit karena hilangnya makna-makna di dalam syairsyair yang mengiringinya.

Para musisi pada masa peradaban Islam berhasil menciptakan berbagai alat musik yang kemudian dikembangkan dan menjadi cikal bakal alat musik yang ada di dunia. Berikut ini alat musik yang diwariskan musisi islam di zaman kekhalifahan Abbasiyyah dan kemudian dikembangkan musisi Eropa pascaRenaisans :

(1) Alboque atau Alboka, merupakan alat musik tiup, terbuat dari kayu berkembang di era keemasan Islam. Nama ini berasal dari bahasa Arab albuq (البوق) yang berarti terompet, yang menjadi cikal bakal terompet modern. Instrumen musik alboka telah digunkaan oleh musisi Islam di masa kejayaan. Alat musik tiup ini diperkenalkan umat islam kepada masyarakat Eropa saat pasukan Muslim dari Jazirah Arab berhasil menaklukan semenanjung Iberia wilayah barat daya Eropa yang terdiri atas Spanyol, Portugal, Andora, Gibraltar, dan sedikit wilayah Prancis. Tidak heran jika masyarakat Eropa meyakini bahwa Alboque berasal dari Spanyol khususnya Madrid (Immamuddin, 1969: 150).

(2) Qanun (Kecapi Arab), dan Lute $(' U d)$, adalah alat musik dawai, dan dimainkan sejak Abad $10 \mathrm{M}$. Bentuk alat musik qanun seperti trapezium dengan papan suara yang datar untuk 81 dawai, yang dibagi menjadi 3 kelompok akord. Cara memainkan alat musik ini dengan meletakkan diatas pangkuan atau meja, dibunyikan dengan petikan jari dimana terdapat 4 plektrum dipasang pada ujung 4 jari (bukan jempol) setiap tangan, dawai ditumpu oleh penunjang (brigde) pada kulit domba yang menutupi sebagian qanun yang segi empat (jadi suara dibuat dengan resonasi kulit domba tersebut. Pemain juga akan membuat māqām baru dengan tangannya. Alat musik qanun adalah salah satu alat musik yang ditemukan oleh Al- 
Farabi. Alat musik ' $U d$ merupakan penanda utama yang membedakan musik Arab dari musik Yunani. ' $U d$ merupakan instrumen musik yang sangat populer dikalangan musisi bangsa Arab. Alat musik ' $U d$ juga populer di wilayah Azerbaijan (Fuadi, 2005:18). Masyarakat di wilayah tersebut menyebut alat musik petik ini disebut ' $U d$. Masyarakat Eropa Barat mulai menggunakan dan mengenal alat musik ' $U d$ sejak tahun $711 \mathrm{M}$. Alat musik petik khas umat islam ini hampir sama dengan pandoura yang dikembangkan peradaban Yunani Kuno atau pandura alat musik bangsa Romawi. ' $U d$ merupakan instrumen musik yang sangat populer dikalangan musisi dan penyanyi Arab sejak masa praislam dan masih dianggap sebagai instrumen musik khas Arab sampai saat ini. Zyriab merupakan pemain 'Ud termashyur di Andalusia, ia pernah mengukir beberapa terobosan bersejarah, antara lain menyusun ulang teori musik, mengembangkan parameter-parameter ritmis dan metris bebas, menambahkan senar kelima dalm oud dan menciptakan cara-cara baru berekspresi. Ia tercatat sebagai pendiri sekolah musik pertama di Spanyol. Menurut cendikiawan islam yang juga musisi terkemuka era keemasan Al-Farabi, ' $U d$ ditemukan oleh Lamech, cucu keenam Nabi Adam.

(3) Hurdy Gurdy dan Instrumen Musik Keyboard Gesek. Alat musik ini merupakan warisan dari peradaban islam di zaman kekhalifahan. Instrumen yang mirip dengan Hurdy Gurdy pertama kali disebut dalam risalah musik Arab. Alat musik ini dapat didengar hingga jarak 60 mil.

(4) Timpani. Alat musik timpani (tambur atau genderang) berasal dari Naqareh Arab. Alat musik pukul ini diperkenalkan ke benua Eropa pada abad ke-13 M oleh orang Arab dan tentara perang Salib. Alat musik timpani merupakan alat musik ritmis yang terbuat dari bahan kuningan dan tabungnya berbentuk menyerupai mangkuk, cara memainkan alat musik ini adalah dengan cara dipukul dengan alat yang dinamakan stik atau mallet timpani.

(5) Naqqāra atau Naker, yaitu drum Timur Tengah dengan punggung bundar dan kepala bersembunyi, biasanya dimainkan berpasangan. Istilah naqqāra berasal dari bahasa Arab yaitu (نقر) yang artinya memukul. Alat musik ini sering dimainkan secara berpasangan, dimana satu naker akan menghasilkan ketukan nada rendah yang disebut nard dan yang lainnya untuk ketukan nada tinggi. Alat musik ini dimainkan dengan cara dipukul dengan tongkat kayu pendek yang ditekuk kearah luar di ujung atas yang disebut damka.

(6) Rebab (Rebec) dan rebab biola modern yang saat ini berkembang pesat di dunia Barat ternyata juga berawal dan berakar dari dunia islam. Alat musik gesek tersebut diperkenalkan oleh orang Timur Tengah kepada orang Eropa pada masa kejayaan kekhalifahan Islam. Biola pertama berasal dari Rebec dan ditemukan pada abad ke-10 M. Cikal bakal biola adalah rebab yang merupakan alat musik khas Arab. Ukuran rebab biasaanya kecil, badannya bulat, bagian depan yang tercakup dalam suatu membran seperti perkamen atau kulit domba dan memiliki leher panjang terpasang. Ada leher tipis panjang terpasang dengan pegbox pada akhir dan ada satu, dua atau tiga senar. Alat musik ini dibuat tegak, baik bertumpu dipangkuan lantai, serta busurnya biasanya lebih melengkung dari pada biola. Alat musik rebab ditemukan oleh Al-Farabi, ia sekaligus dikenal sebagai pemain rebab yang handal. Alat musik yang ada pada masa peradaban Islam kemudian diterapkan dan dikembangkan oleh masyarakat Barat sampai saat ini, sehingga seni pada masa kekhalifahan telah berhasil menyumbangkan beragam warisan penting terutama dalam dunia seni musik bagi masyarakat di era modern seperti sekarang. Pencapaian yang tinggi di bidang musik menunjukkan betapa masyarakat muslim telah mencapai peradaban yang sangat tinggi di abad pertengahan. 


\section{Jenis-jenis Musik Ciptaan Al-Farabi}

Banyak jenis musik yang di ciptakan Al-Farabi yang digunakan sebagai media mengekspresikan perasaan seseorang dalam kehidupan sehari-hari, karena jenis musik yang mewakili suasana hati seseorang tidak selalu sama. Berikut ini adalah beberapa jenis musik yang diciptakan Al-Farabi, diantaranya: (1) Māqūm Rāst, adalah nada yang dapat membangkitkan perasaan berfikir positif, kebanggan hati, kesehtan pikiran, dan maskulinitas. Māqām Rāst membuat hati menjadi tenang karena nada yang disusun memang dibuat untuk menenagkan hati. Jenis musik ini juga digunakan sebagai penyembuhan untuk jiwa yang sakit agar kembali bersemangat. (2) Māqām Bāyātī, adalah jenis nada yang menumbuhkan rasa suka cita dalam jiwa, menimbulkan kebahagiaan, imajinasi dengan perasaan jiwa yang tenteram akan memicu hati menjadi lapang serta berbahagia pada saat mengalami momen yang menyenangkan hati. Māqām Bāyātī ini adalah $m \bar{a} q \bar{a} m$ wajib yang selalu digunakan dalam tradisi musik Arab dari zaman dahulu sampai sekarang. Māqām ini juga sering digunakan dalam pembacaan lantunan ayat suci Al-Qur'an. (3) Māqām Sīkāh, adalah satu $m \bar{a} q \bar{a} m$ yang sering digunakan pada saat seseorang sedang jatuh cinta. Irama ini dapat mengantarkan kepada jiwa yang rindu akan kasih sayang Allah karena telah lama jiwanya merasa sepi. (4) Māqām $S \bar{a} b \bar{a}$, adalah jenis $m \bar{a} q \bar{a} m$ yang memicuperasaan haru dan menyentuh. Musik ini bukan hanya membuat yang mendengarnya akan merasa bahagia karena terharu oleh keindahannya akan tetapi juga menimbulkan bekas yang tidak akan pernah dilupakan. (5) Māqām $H \bar{y} j \bar{a} z$, adalah $M \bar{a} q \bar{a} m$ yang menghasilkan perasaan jiwa jauh kedalam lubuk hati yang terdalam. Perasaan yang tercipta dari emosiemosi dalam jiwa yang berasal dari pengalaman alami seseorang dapat menuntun kedalam lubuk jiwa terdalam menuju kedekatan dengan Tuhan.

Māqūm Nāhwānd, adalah māqūm yang dapat menimbulkan perasaan merenung atau tempat berfikir. Berfikir disini mengarah kepada rasa kesedihan yang memilukan akan tetapi tidak terlalu dalam melubuk hati hingga seorang tersebut merasa pedih. (7) Māqām Jīhārkāh, adalah māqūm yang memberikan kesan manis dan mengharukan. Iramanya selalu mendorong perasaan yang mendalam. (8) Māqām Ājām, yaitu alunan yang cemerlang akan menimbulkan keceriaan dalam jiwa siapa saja. Māqām ini bermanfaat untuk jiwa yang sepi dan kosong, jiwa yang merasa jauh dari kebahagiaan dan keramaian hidup. (9) Māqām Kûrd, adalah māqām yang digunakan untuk membuat siapa saja akan terbahak-bahak jika mendengarnya. (10) Māqām İ $\bar{a} q \bar{\imath}$, adalah suatu irama musik menandakan sebuah peristiwa yang genting dan menyeramkan.

Jenis-jenis irama musik yang disampaikan Al-Farabi diatas dapat memberikan manfaat bagi manusia, karena musik tidak hanya bisa digunakan sebagai hiburan saja, akan tetapi musik juga mampu mempengaruhi moral, mengendalikan emosi, mengembangkan spiritualitas, dan menyembuhkan penyakit seperti gangguan psikosomatik. Karena itulah musik dapat digunakan sebagai alat terapi.

\section{Musik sebagai Media Terapi}

Komposisi susunan musik yang mengandung makna baik dan benar akan membuat jiwa manusia semakin tentram dan damai, untuk menumbuhkan ketentraman jiwa, penanganan yang tepat jiwa harus diarahkan dengan sederet kata dan syair bermakna yang menyentuh hati, karena keindahan suatu karya adalah tercurahnya suatu perasaan yang ditumpahkan ke dalam sebuah syair yang baik. Inilah saat yang tepat untuk lebih dekat dengan Tuhan karena jiwa telah mendapatkan kedamaiannya sehingga sampai pada hal yang baik. Musik dikaitkan sebagai media penyembuhan dalam peningkatan kualitas individu atau kelompok. Hal ini dapat memberikan gambaran adanya hubungan antara musik dengan respon seseorang yang sebenarnya tidak jauh dari hubungan emosi 
antar musik dan pendengar (Djohan, 2006). Oleh karena itu pendengar dapat merasakan ketenangan maupun kedamaian dengan mendengarkan musik secara tiba-tiba.

Terapi musik sangat efektif digunakan dalam tiga bidang pengobatan, antara lain: (1) Sakit kecemasan, depresi. Terapi musik efektif digunakan untuk mempermudah komunikasi dalam proses penyembuhan dari klien yang mengalami penyakit berat dan memutuskan untuk menarik diri. (2) Cacat mental, emosi, dan fisik. Terapi musik banyak digunakan untuk orang-orang yang mengalami gangguan emosional, karena retradisi mental, autis, dan gangguan kemampuan belajar. (3) Gangguan neutrologis. Musik melibatkan kedua belah hemisfer otak saat dipedengarkan sehingga merangsang respon dari klien.Sejak awal sejarah manuisa musik telah memainkan peran yang signifikan dalam hal penyembuhan manusia. Pada zaman Yunani kuno Dewa Apollo selain sebagai dewa musik juga sebagai dewa pengobatan. Pada masanya musik diyakini sebagai seni yang dikaruniai kekuatan untuk menembus kekuatan jiwa, bahkan dalam alirang gaib Arab dan Yunani penyembuhan dengan suara dianggap sebagai pengetahuan sakral tingkat tinggi. Kekuatan musik sebagai media penyembuhan pada jaman dahulu diketahui dari kitab suci dan tulisantulisan peninggalan sejarah Arab, Cina, Yunani, dan Roma (Djohan, 2003:83-84).

Terapi musik adalah tipe terapi nonverbal yang berbeda dengan terapi konvensional lainnya karena terapi musik memberikan alternatif bagi terapi tradisional dan melengkapi klien dengan beberapa keunggulan seperti : (1) memberikan peluang berpikir serta merasakan secara langsung; (2) memberi peluang "mengisi" perasaan untuk beberapa periode sehingga bisa dieksplorasi, diuji, dan diolah lewat kerja sama dengan terapis; (3) mengkondisikan ekspresi pikiran dan perasaan klien secara non verbal; (4) diperoleh perumpamaan dan asosiasi yang tidak dapat diakses melalui pemahaman verbal; (5) diperoleh keuntungan fisiologis secara langsung melalui kebebasan bereksplorasi dan mencoba berbagi solusi terhadap pikiran dan perasaan melalui caracara yang kreatif (Djohan, 2003: 190-191).

Terapi musik bermanfaat untuk memberikan rasa nyaman, menurunkan stres, kecemasan dan kegelisahan, serta melepaskan tekanan emosional yang dialami. Tujuan tersebut dapat tercapai melalui berbagai kegiatan yang dapat dilakukan dalam terapi musik, seperti menyanyi, bermain musik, mendengarkan musik, menyaksikan video musik, menulis lagu atau aransemen musik, dan berdiskusi tentang musik (Lindberg, 1997).

Sebagai seorang musisi Al-Farabi juga berpendapat bahwa Musik adalah hasil kreasi dari susunan lagu dan suara. Ia merupakan hubungan dari pembentukan irama sesuai dengan ukuran jenis yang telah dihitung ukuran rendah tingginya nada. Pada dasarnya musik adalah hal naluri manusia yang diciptakan karena kebutuhan dan kesenangan batin terhadapnya. Dengan mengeluarkan lagu dari sisi-sisi yang beragam ketika ia terketuk kedalam jiwa, jiwa merasa adanya kenikmatan yang berdampak pada kesehatan dan ketenangan saat terjadi ketukan, jika sebaliknya maka jiwa merasa gelisah dan sakit karena hilangnya makna-makna di dalam syairsyair yang mengiringinya (Al-Farabi, tt:11). Akan tetapi syair pada masa awal islam tidak mendapatkan perhatian dari banyak orang, hal itu dikarenakan pada zaman Arab sebelum islam status syair belum dapat digunakan karena dianggap sebagai hal yang tidak layak dan ilegal untuk digunakan. Masyarakat di zaman tersebut menganggap bahwa syair musik akan membawa dampak negatif dan merusak akhlak bagi setiap orang yang mendengarkan musik.

Biddle dan Thomas (1996) menjelaskan indikator dimensi peran adalah peran sebagai strategi, yaitu peran merupakan strategi untuk mendapatkan dukungan dari masyarakat. Dalam hal ini 
Al-Farabi tidak pernah menyerah meyakinkan masyarakat yang masih tertutup oleh keyakinan lama. Beliau bersikeras membangun kepercayaan masyarakat mengenai musik karena, musik itu baik jika memiliki syair yang isinya manfaat dan hanya memohon untuk kebaikan apalagi jika tujuannya berdoa kepada Tuhan demi mengharap keridhonnya. Pada dasarnya syair puji-pujian didapatkan melalui renungann yang khusuk agar manusia tidak salah mengenal Tuhan dan Rasul (AlFarabi, tt:28). Pujian yang disampaikan untuk Nabi sudah pasti mengandung unsur kebaikan yang mana membawa seni musik bersyair pujian Nabi ini membawa pengaruh besar yang berdampak baik untuk kemakmuran bangsa Arab. Kebaikan musik dengan syair ini dapat kita dengarkan dalam qasidah dari pencipta yang sangat mencintai Nabi (Al-Farabi, tt:33).

Salah satu sumber terciptanya irama musik berawal dari suara lantunan azan pertama yang dikumandangkan oleh Bilal bin Rabbah pada zaman nabi Muhammad SAW.Dari satu jenis nada tersebut maka semakin berkembang memunculkan jenisjenis nada yang baru atau disebut dengan māqām. Māqām ialah jenis irama khusus yang mempunyai teknik yang berkarakter yang tidak akan berpindah dan berubah seiring berjalannya waktu. Satu buah nada irama dari māqūm sudah memiliki satu karakter yang tidak bisa diubah kembali nada-nadanya, jadi nada yang sudah mendapat nama telah menjadi satu kesatuan nada yang tersusun sesuai dengan perhitungan dinamika iramanya.

\section{Manfaat Musik menurut Al-Farabi}

Menurut Al-Farabi musik dapat memberikan manfaat untuk kehidupan manusia diantaranya;

(1) Manfaat musik untuk jiwa. AlFarabi menjelaskan manfaat musik bagi jiwa manusia, karena jiwa yang terganggu akan sulit untuk menerima masukanmasukan yang berguna demi kesembuhan mentalnya, manusia dapat terhindar dari gangguan mental jika manusia mejauh dari ketegangan, perasaan lelah,cemas, sakit hati, yang hal tersebut akan menganggu kegiatan sehari-hari. Manusia seharusnya selalu berfikir positif sehingga manusia mampu mengembangkan potensi yang ia miliki. Setiap manusia memiliki jiwa dan perasaan yang berbeda-beda. Musik dapat mendorong jiwa manusia yang lemah menjadi kuat dengan menyeru jiwa secara lembut agar dapat merasakan perasaan damai.Caranya adalah dengan mendengar musik sesuai dengan jenis jiwa terlebih dahulu.

(2) Manfaat musik untuk spiritual. Musik adalah satu-satunya jalan untuk mengeluarkan atau menembus suatu yang ada dalam hati yang paling dalam dan bersifat halus serta tersembunyi. Maka dengan suara-suara merdu yang disusun sedemikian rupa hingga tercipta suatu irama yag harmonis akan dapat menyentuh rahasia itu dan terbukalah hijab dan dapat mengantarkan manusia menuju tingkatan spiritual yang paling tinggi. Bagi para filsuf islam, teori aliran musik spiritual ada dua, yaitu revalasionisme dan naturalisme. Revalasionisme berusaha mempercayai musik berasal dari alam metafis melalui tersigkapnya tabir atau proses pewahyuan. Arus pemikiran ini berpusat pada pandangan bahwa musik merupakan bunyi yang dihasilkan oleh suara dalam jagad raya. Melalui kuasa Tuhan, alam raya ini diciptakan dan disususn dengan komposisi terbaik pula, dengan seluruh gerakannya yang mengandung komposisi terbaik pula. Filusuf yang masuk dalam kategori ini adalah Ikhwan al-Safa dan al-Kindi. Bagi Ikhwan al-Safa, musik yang ada di bumi mencerminkan musik yang terdapat di langit serta mengilustrasikan suatu jalan kepada ketinggian spiritual dalam menapaki dunia eksistensi yang lebih tinggi. Sementara itu, menurut Al-Kindi, musik adalah sistem harmoni yang bertalian dengan kesinambungan lahiriah dan emosional dan dapat digunakan sebagai terapi kesinambungan hidup. Adapun aliran yang kedua yaitu Naturalisme, berpandangan 
bahwa manusia dengan fitrahnya adalah makhluk yang berkesenian sekaligus menciptakan musiknya. Aliran ini beransumsi kemampuan manusia untuk menciptakan musik merupakan fitrah, sebagaimana kemampuan alamiah manusia dalam mendengar, melihat, dan berjalan. Disamping itu, menurut aliran ini, musik adalah bagian dari budaya manusia karena ia tumbuh dan berkembang bersamaan dengan proses perkembangan manusia. Aliran yang diwakili oleh Al-Farabi dan Ibn Sina ini menegaskan bahwa apa yang penting dari musik adalah kemampuannya untuk membuat manusia menikmati bunyi atau suara.Al-Farabi berpendapat bahwa apabila imajinasi bisa menciptakan semua ilustrasi, maka ia dapat membentuk ilustrasi-ilustrasi tersebut dengan bentuk alam rohani, makna yang mendorong manusia untuk segera dekat dengan penciptanya akan menambah semangat jiwa untuk taat beribadah. Salah satu jenis musik yang digunakan untuk lebih dekat dengan Tuhan dalam sejarah musik Arab dapat menggunakan musik māqām. Musik māqām yang paling tepat adalah dengan menggunakan jenis māqām hìjāz. Cara menggunakannya dengan mendengarkan jenis musik ini lalu menghayati hingga masuk ke dalam jiwa terdalam. Salah satu jenis musik yang bisa digunakan untuk mendekatkan diri dengan sang pencipta adalah musik qasidah dan musik gambus, selain memiliki irama yang menenangkan, musik tersebut dapat mendorong seseorang menemukan kesadaran diri untuk lebih dekat dengan Allah SWT melalui syairsyairnya, karena syair-syair yang terdapat dalam musik qasidah dan gambus tersebut biasanya berisi mengenai puji-pujian kepada Allah SWT dan curahan kerinduaan terhadap Nabi Muhammad SAW. Contoh lain pada saat seseorang ingin merasakan kebahagiaan masa depan dengan cara mendengarkan musik lalu musik tersebut masuk kedalam jiwa, setelah terlena secara langsung otak akan merespon dan mendorong imajinasi untuk berjalan lebih dalam dan jauh ke dalam lubuk hati yang terdalam. Imajinasi harus dihubungkan dengan jiwa yang telah terpisah dari satu jiwa yang lain, jiwa yang lain adalah jiwa aktif yang terhubung dengan Allah SWT. Jiwa yang terhubung dengan Allah SWT akan merasakan suatu ketenangan dan ketentraman karena ia sang maha pemberi ketenangan dan kebahagiaan.

(3) Musik sebagai media terapi untuk penyembuhan penyakit psikosomatik. adalah gangguan fisik yang disebabkan oleh faktor-faktor kementalan dan sosial. jika emosi seseorang menumpuk, maka hal tersebut dapat mengakibatkan terjadinya goncangan dan kekacauan dalam dirinya. Jika hal tersebut terjadi secara terus menerus, maka ia akan dipaksa untuk menekan perasaannya. Perasaan tertekan, cemas, kesepian dan kebosanan yang berkepanjangan dapat mempengaruhi kesehatan fisik. Kecemasan akan membuat perubahan fisik pada orang seperti cepatnya debaran jantung, tekanan darah tinggi, hilangnya selera makan, nafas tidak teratur, keringat dingin, susah tidur bahkan dapat mengakibatkan pingsan. Seseorang sebaiknya mencoba untuk mengelola stres, kecemasan, dan depresi yang dialami, agar tidak mengalami gangguan psikosomatik yang akan mempengaruhi kondisi tubuh secara keseluruhan. Gangguan spesifik yang terjadi pada penderita psikosomatik yaitu; konflik dan gangguan jiwa dapat menimbulkan gangguan badaniah yang terus menerus, biasanya hanya menyerang satu alat tubuh saja, akan tetapi terkadang juga berturut-turut atau serentak beberapa organ yang terganggu. Jenis gangguan dibagi menurut organ yang paling sensitif, yaitu kulit, otot dan tulang, saluran pernapasan, saluran penceraan.Musik menurut Al-Farabi dapat dijadikan sebagai salah satu media untuk terapi penyembuhan psikosomatik, karena ketika musik diaplikasikan menjadi sebuah media terapi, maka ia dapat meningkatkan, memulihkan, serta memelihara kesehatan fisik, mental, emosional, sosial, dan spiritual 
individu.Terapi musik sangat efektif dalam meredakan kegelisahan dan stress, mendorong perasaan rileks, meredakan depresi dan mengatasi insomnia. Para ilmuwan muslim memilki peranan penting dalam membuat musik menjadi media kesehatan untuk jiwa manusia. Berdasarkan penjelasan empiris dan filosofis musik mereka, dalam waktu abad pertengahan banyak Rumah Sakit Muslim menyewa terapis musik profesional untuk dijadikan bagian dari tim perawatan pasien. Setiap biaya yang terkait dengan terapi musik ditanggung oleh organisasi amal atau oleh negara. Berdasarkan pengalaman pasien, musik adalah alat berharga dalam perawatan spirirual islam untuk menghasilkan peningkatan yang signifikan dalam kesehatan emosional, spiritual, mental, dan kesehatan pasien.

\section{Kesimpulan}

Seni musik mengalami perkembangan yang sangat pesat pada masa Dinasti Abbasiyah dengan dipengaruhi oleh asimilasi antar bangsa Arab dan etnis-etnis lain yang terlebih dahulu mengalami perkembangan dalam bidang seni. Seni musik memiliki peran yang penting dalam penyebaran agama Islam, pada era abbasiyah seni musik mengalami kemajuan yang begitu pesat di antaranya terbukti munculnya banyak musisi yang terkenal pada masa tersebut antara lain: Sa'ib Khathir, Tuwais, Ibnu Mijjah, Ishaq alMausili, Al Kindi, dan Al-Farabi (872-950).

Al-Farabi mengemukakan bahwa musik memiliki manfaat dalam kehidupan manusia diantaranya;(1) Manfaat musik untuk jiwa, karena jiwa yang terganggu akan sulit untuk menerima masukanmasukan yang berguna demi kesembuhan mentalnya, manusia dapat terhindar dari gangguan mental jika manusia menjauh dari ketegangan, perasaan lelah, perasaan cemas, perasaan sakit hati, yang hal tersebut akan menganggu kegiatan sehari-hari. Manfaat musik untuk spiritual, jenis musik ini terdapat dalam musik qasidah dan musik gambus, seseorang yang mendengarkan musik ini akan didorong untuk menemukan kesadaran diri untuk lebih dekat dengan Allah SWT melalui syair-syairnya, karena syair-syair yang terdapat dalam musik qasidah dan gambus tersebut biasanya berisi mengenai puji-pujian kepada Allah SWT dan curahan kerinduaan terhadap Nabi Muhammad SAW. (3) Manfaat musik sebagai media terapi untuk penyembuhan penyakit psikosomatik, Musik dapat menjadi media terapi untuk penyembuhan penyakit stres yang di hadapi seseorang. Ketika musik diaplikasikan menjadi sebuah media terapi, maka ia dapat meningkatkan, memulihkan, serta memelihara kesehatan fisik, mental, emosional, sosial, dan spiritual individu. Terapi musik sangat efektif dalam meredakan kegelisahan dan stress, mendorong perasaan rileks, meredakan depresi dan mengatasi insomnia.

\section{Daftar Pustaka}

Al-Farabi. T.T. Musiq al-Kabir. Cairo: Daar el Katib.

Anam, Khoirul, 2017. Musik Spiritual (Telaah Filosofis). Tesis Program Studi Filsafat Agama. Pascasarjana Universitas Islam Negeri Sunan Ampel. Surabaya.

Biddle, B.J dan Thomas, E.J. 1966. Role Theory : Concept and Research. New York: Wiley.

Djohan. 2003. Psikologi Musik. Yogyakarta: Buku Baik.

---------. 2006. Terapi Musik Teori dan Aplikasi. Yogyakarta: Galang Press.

Imam Skardi, 2007. Puncak Kabahagiaan (Al-Farabi) Etape-Etape SufistikFilosofis Meniti Revolusi Hidup. Yogyakarta: Pustaka Pelajar. 
Khudori Soleh, 2010. Integrasi Agama dan Filsafat Pemikiran Epistimologi AlFarabi. Malang: UIN-Malki Press.

Departemen Pendidikan dan Kebudayaan. 2008. Kamus Besar Bahasa Indonesia. Jakarta: Balai Pustaka.

Eduarny Tarmiji. 2004. "Konsep Al-Farabi tentang Negara Utama", tesis magister. Jakarta: Fakultas Sastra Universitas Indonesia.

Harimurti, Shubhi Mahmashony Harimurti. 2015. Seni Pada Masa Pemerintahan Dinasti Abbasiyah Tahun 711-950 Masehi. Yogyakarta: Universitas Islam Indonesia.

Isgandarova, Nazila. 2015. Music in Islamic Spiritual Care: A Review of Classical Sources. Emmanuel College Ofvictoria University. Vol 34 No 1

Merrit,S. 2003. Simfoni Otak: 39 Aktivitas Musik yang Merangsang IQ, EQ, SQ untuk Membangkitakan Kreativitas dan Imajinasi. Bandung: Kaifa.
Merriam, A.P. 1964. The Anthropology of Music Chicago : North Western University Press.

Merriam,A.P. 1968. The Anthropology of Music Chicago : North Western University Press.

Margono S. 2007. Metologi Penelitian Pendidikan Komponen MKDK. Jakarta: PT. Rineka Cipta.

Muhaya, Abdul. 2003. Bersufi Melalui Musik: Sebuah Pembelaan Musik Sufi oleh Ahmad al-Ghazali. Yogyakarta: Gama Media.

Michon, Jean Louis "Musik dan Tarian Suci dalam Islam” dalam Seyyed Hossein nasr, ed, Ensiklopedia Tematis Spiritual Islam, Manifestasi. Terj. M. Sholihin Ariyanto, Ruslani, M.S. Nasrullah, Dodi Salman, Kamamdin SF. Bandung: Mizan.2003.

Nasr, Seyed Hossein. 1987. Spiritualitas dan Seni Islam, terj. Sutejo. Bandung: Mizan. 